Poznańskie Studia Teologiczne 27(2013), s. 81-89.

Horst Bürkle

Starnberg, Deutschland

\title{
"Peace" - a basic issue in the Christian dialogue with Asian religions
}

\section{Preface}

Search for peace is a major concern of man. It finds its expressions in the religions of mankind. The answers which the religions give to this basic human desire differ. Especially in religions like Buddhism and Hinduism «peace» is understood as the overcoming of the painful experiences and sufferings of this life.

If the term "peace" is used to-day in modern interpretations of Asian religions' it is already the result of an interreligious dialogue with western especially with Christian terminology. "Peace" is understood as a present day and an actual desire of mankind in a world of conflicts and tensions. The messages of Hindu-and Buddhist religious answers go deeper. They aim to the roots of unrest in human life. In this respect they share with the Christian answer the outlook for peace which points beyond the present life. "Our heart is restless until it finds its rest in Thee". This confession of St. Augustine is a basic human concern. But the specific Christian answer is found in the second part of this confession of St. Augustine: "[...] until its finds its rest in Thee." Here we have both: The common human concern of all men: unrest and search for peace - for overcoming all what determines our life and makes it a peaceless experience of pain and suffering. The second part of Augustine's confession is the Christian orientation: "[...] until it finds its rest in Thee". This is the respond to our trust in Christ - the savior from our unrest: He is our peace. Both parts of St. Augustine's confessions show to us the basic relation to men of other religions and what is still the difference between their concerns and our Christian faith: Our solidarity with men in their own religions and at the time it shows what we do not have in common with them. When we enter now into our short dialog on "Peace" with people in other religions we shall keep (this) in mind: Our human condition unites us with all men. The ways of overcoming this situation of mankind differ. The view in all religions goes beyond this life-time. It aims toward something whose reality is a new one. And this new reality has great influence for this limited and conditioned life. We keep in mind: If we use the term "Peace" for this new reality then we 
transfer our Christian terminology into other religious horizons. And indeed: We find this word "Peace" to-day among the leading representatives of Hinduism and Buddhism. This again is the result of interreligious exchange and mutual influences. Eirana, pax, peace - these words refer originally to a terminology which has its roots in the Hebrew and Christian tradition. In the Old Testament peace for Israel is the gift of Jahveh's gracious guidance of his people. The outlook to permanent peace is part of the final messianic future. From peace on earth the hope turns to everlasting peace of this fulfillment of all prophecy. This hope for peace is expressed in various ways in the ambiguous history of Israel. In the Christ-event, in Jesus of Nazareth, in his life, cross and in his resurrection this messianic hope is fulfilled: "I am your peace". Athens and Rome have contributed in the New Testament their own concepts of peace. The Mediterranean world had its own concepts of "peace". We find them among the pre-Socratic thinkers of Greece. It is a major topic in Plato's philosophy. As fruit of the logos it is of divine nature. The expectations in the Roman imperial times where orientated toward lasting peace. "Pax Romana" - a political concern - was connected with the divine personality of the emperors. The cult was committed to them, which had to safeguard this pax Romana. These pre-Christian desires and hopes for peace, their philosophical reflections and their religious dimensions are in the background of the peace-fulfilling Christ-event. They have influenced the terminology of the New Testament. Like John the Baptist they prepared the way to this final fulfillment of «peace». Modern representatives of Asian religions interpret the central contents of their religions in terms of the Western and Christian term «peace». Let us look at some outstanding examples how their basic religious concerns are seen in the light of this peace.

\section{Mahatma Gandhi's new interpretation of salvation in Hinduism}

"My religion is Hinduism which is for me the religion of mankind. It includes the most best of all religions known to me." This confession to the universal message of his Hinduism is the result of his new interpretation and practice of this religion as a way to inner peace and rest. Here his statement: "I enjoy myself a peace and a equality of the mind which made many of my Christian friends envious. ...I find comfort in the Bhagavadgita and in the Upanishads which even did not find in the Sermon on the mountains". ${ }^{1}$

Gandhi's concern for peace is rooted in his Hindu-tradition. Not destroying any kind of life - ahimsa - is required in the Bhagavadgita. Doing harm to other beings will have negative consequences for my own next rebirth. To be abstinent from any conflict and involvement results in a kind of spiritual asceticism. By

\footnotetext{
${ }^{1}$ O. Wolff, Indiens Beitragzum neuen Menschenbild, Hamburg 1957, p. 87.
} 
practicing it man collects energy and power which enables him not only to overcome all sufferings in life. It even creates the strengths to overcome the enemy. Gandhi develops this religious discipline into a successful method of political resistance and liberation. Influenced by the Christian ethical concern for love toward my neighbor ahimsa grows for him into a way of universal apeacement and salvation for mankind. For this universal aim of creating peace through Hindu-ahimsa love as the gift of Christ in his divine mission appears to Gandhi as an outstanding example. The Christ-event remains for him to be the personification and demonstration of what is based in Hindu-ethics. The way to it leads to self-discipline and meditative control.

There is no question: His universalization of the Hindu concept of non-attachement (ahimsa) was inspired by the message of Jesus of Nazareth ("Love your neighbor as yourself"). But he separated this message from the Christ-event as the very fundament for this new ethic. For his critics - especially for the first president of the new Indian republic Pandid Nehru - this ideal Hindu-based peace could not work in the realm of political responsibilities.

For many people Gandhi represented the rebirth of the Indian heritage. His 'Hindutum' seemed to offer answers to the problems and conflicts of the modern world. But he was not the first one who was a messenger in his life and in his work of India's spiritual heritage. Ram Mohan Roy, called "father of new India", and Svami Vivekananda had been messengers of a universal message which India owed to the rest of the world.

For many he seemed to be a hidden pupil of Christ. The spirit of the sermon on the mountain appeared to be the key to his universal message of love and peace. But Gandhi's own confession sounds different. On a conference of Christian missionaries in Calcutta on July $28^{\text {th }}, 1925$ he states: "I am ... not a Christian. And I am here, in order to tell you in all my humbleness: Faith in Hinduism as I understand it, give complete satisfaction to my soul and is fulfillment for my whole being." According to his Hindu-background for Gandhi there was no need to distinguish what was a basic distinction for the Christian faith "My kingship is, not from this earth" - The misunderstanding of this new reality of peace we see in the background of the Golgotha-event. Only the risen Christ in his new presence is the guaranty for peace everlasting.

That Gandhi's ahimsa-based Hindu-Christian peace-concept missed the concrete situation is shown to me by two examples.

In the Christmas-week 1941 Gandhi wrote a personal letter to Adolf Hitler. German forces had just occupied France. The Government of India - at that time British - did not allow the letter to be transmitted to Hitler. "Dear Friend: That I address you as a friend is no formality. No foes. My business in life has been for the past thirty-three years to enlist the friendship of the whole humanity by befriending mankind, irrespective of race, colour or creed... Here follows a longer 
demonstration of his own non-violence, i.e. unarmed revolt against the British rule "We have attained a very fair measure of success through non-violent effort" ... I, therefore, appeal to you in the name of humanity to stop the war. You will lose nothing by referring all the matters of dispute between you and Great Britain to an International Tribunal of your joint choice."2 A tribunal for peace would have been the last thing Hitler would have thought of after 2 successful fast occupations (Poland and France).

The second example refers to the situation of the Jews in Germany at that time. After a recourse to his experiences with non-violence resistance in South Africa Gandhi recommends this method: "But the Jews of Germany can offer Satyagraha under infinitely better auspices than the Indians of South Africa. The Jews are a compact, homogeneous community in Germany. They are far more gifted than the Indians in South Africa. And they have organized world opinion behind them. I am convinced that, if someone with courage and vision can arise among them to lead them in non-violent action, the winter of their despair can in the twinkling of an eye be turned into the summer of hope". ${ }^{3}$ His concept of a satyagraha - based peace refers also to the Jewish - Arab conflict in Palestine. "They can settle in Palestine only by good-will of the Arabs. They should seek to convert the Arab heart. The same God rules the Arab heart who rules the Jewish heart. They can offer satyagraha in front of the Arabs and offer themselves to be shot or thrown into the Dead Sea without raising a little finger against them". ${ }^{4}$ Peace of mankind through the fulfillment of a universal concept of the Hindu s a t is also the solution for the troubles of the persecuted Jews in Germany for Gandhi: "The German Jews will score a lasting victory over the German gentiles in the sense that they will have converted the latter to an appreciation of human dignity." Concerning the establishment of a Jewish state in Palestine Gandhi seems to distinguish between the religious hope of the Jews and its political realization: "I have no doubt that they are going in the wrong way. The Palestine of the Biblical conception is not a geographical tract. It is in their hearts." Gandhi seems to interpret the history of Israel with its God in the dimension which the New Testament has opened to him. The prophetical messages to their people are not yet being fulfilled in this time and geography. They point as a 'principle of hope' beyond this time. But at the same time they give man God's own orientation in his political and regional behavior. They cannot be overcome by certain political concepts but they provide the horizon for finding peace in an ongoing political world and its conflicts.

\footnotetext{
${ }^{2}$ M.K. Gandhi, My Non-Violence, Ahmedabad 1960, p. $158 \mathrm{f}$.

${ }^{3}$ Ibidem, p. 73.

${ }^{4}$ Ibidem, p. 74.
} 


\section{A new Buddhist message for peaceful existence}

I refer to the last representative of the famous school of modern Budhism: Keji Nichitani at the university of Kyoto (1900-1990). In dialogue with the Christian tradition and with Western existential philosophy he interprets Buddhist thoughts for man to-day. In his basic work "Religion - what is it all about" (1961) the central experience of nirvana is the base for every desire for salvation and peace in mankind. The suffering and the death of Jesus of Nazareth is seen by him as the overwhelming example for Buddha's universal message of nirvana. His kenosis shows what nirvana really means. It is not anymore a final goal which man never really is able to reach in this life. Man himself is able to find peace according to Buddha's overcoming of all dependences and sufferings from his existential conditions. My own self has to be changed. It must be turned into a complete new independence. Not to be myself anymore opens the door to 'salvation'. It is the 'New Being'. This radical change means. What Buddha really meant for Nishitani is now seen as the way to everlasting peace and freedom. Man has to offer his self-centered being. Therefore he must give up himself. He must loose himself and his faith in his own personality. He quotes from the preachings of Gautama Buddha where he said: "Oh bikkhu: as an experienced, holy disciple one has discovered the Holy.... He regards this form no longer as himself... his feelings, his perceptions, his distinctions and his conscience not as himself nor within them himself. ... In this way, oh bikkhu, faith in his personality can not exist".

Nishitani finds this original Buddhist denial of the human person in the destiny of Jesus of Nazareth: "No doubt: This concept of man as a person is the highest which we can find so far. The same can be said about God as a personal being. In modern times the subjectivity with its self-consciousness has become nearly the self-conscious as such. But is this form and way to think about «person» as it dominates until to-day the only way to think of «person»". ${ }^{6}$

We ask: Is it possible to interpret the nature of Christ and what lies beyond his personality in terms of Buddha's overcoming of time and history?

For Nishitani the suffering and the cross of Jesus is the highest expression of denying the human self. But it remains an outstanding example. It serves as a demonstration of the way everybody might follow.

For Nishitani it shows the possibility for a new universal ethics for mankind in peace and harmony. But the condition is not understood as God's gift in Christ for man. Jesus Christ's "I am your peace" is not based in his life and mission for us. It remains to serve as a guide not as the base for participation in his saving communion with us. The Buddhist search for anatman is an invitation to ever-

\footnotetext{
${ }^{5}$ Die Reden Gotamo Buddos, Bd. I, Zürich-Wien 1956, pp. 831 f.

${ }^{6}$ Quoted in H. Waldenfels, Faszination des Buddhismus, Mainz 1982, p. 45.
} 
lasting peace in an existence committed to death. The Buddhist dialogue therefore follows the characteristic patterns of the existential philosophy. The early categories of Martin Heidegger are privileged concepts: "Geworfensein", "Eigentlichkeit", "Zeitlichkeit" and others. Martin Heidegger's later 'metaphysical' turn seems not usable anymore for such new Buddhist thinking. But in the Christian-Buddhist dialogue we are reminded: The characteristics of the Christian faith cannot be grasped inside the borders of our existence. It needs the view toward the divine Son who had been with the Father from the beginning of the world and of every being with the Father. His being resurrected, his lordship beyond time, world and cosmos and his final return in glory safeguard a peace which is not from this world and definitely not the result of our human behavior. So far we have seen an example how Buddhism is understood in terms of Western existentialist philosophy for the individual. Now we turn to a Buddhist representative in Sri Lanka. For him Buddhism offers the solution for the problems of society today.

\section{Buddhism for peace in the society}

K.N. Jayatilleke (1920-1970) studied at Cambridge (1946-1949) and at London before he became professor and dean of the faculty of the university of Ceylon. His Buddhism is based on philosophical empiricism as he found it during his time in England. How can religion be reconciled with our knowledge in natural science? In this respect for him Buddhism offers the peaceful co-existence in a modern world based on scientific knowledge. All other religions include pre scientific views of world and society - not so Buddhism. His Buddhism leads him toward a new freedom for research and discoveries. Different from Nishitani and his ZEN-Buddhism is he not interested to include the message of Jesus into his concept of Buddhism. His concern is the secular modern world and society. How can man become free and responsible for himself in a peaceful democratic society? For this aim Jayatilleke has to re-interpret the classic Buddhist thinking. The concept of rebirth had to be given up. Nirvana is now understood as the peaceful coexistence of man in freedom and harmony in his society. Buddha's as cetic withdrawal from desire and from dependences in life is now interpreted as individual independence and responsibility for a peaceful democratic society.

"The freedom which is powerful enough to escape the circle of rebirths is founded only in the ethical 'subject'. It does not need any support by a higher power. Man who safeguards his own luck has trust only in himself. Therefore

${ }^{7}$ G. Rothermund, Buddhismus für die modern Welt: Die Religionsphilosophie K.N. Jayatillekes, Calver Theologische Monographien, Bd. 4, Stuttgart 1979. 
he is "master of his life» in the full sense of the word". ${ }^{7}$ F or Jayatilleke the ideals of freedom and peace in a post-Christian Western world have determined his reinterpretation of Buddhism. He combines them with his musters of strategies for success of the individual. His concept for the society is based on a peaceful harmonic cooperation between individuals. Here again his Buddhism provides the necessary orientation: "In his teachings of the fundamental equality of all men the Buddha-Dharma offers a principle of integration for a world full of conflicts between groups and their interests: All men belong to the same species. This means: There is no base for pride of casts and races and nations. ... There is a sufficient degree of homogeneity among men concerning their capacities and their potentialities in order to require their equality and humanity". 8 What a fascinating new interpretation of Buddha's teachings! Was his nirvana not an aim beyond time and space - an any case it had be e $n$ the opposite of any social and personal engagement? His message of peace sounded differently in terms of non-attachment and giving up of any misleading involvements. In Jayatilleke like in other New-Buddhist thinkers we meet partners when we speak about peace and co-existence to-day. But the Christian-Buddhist dialogue has changed its subject. It has turned from the theological concern to an ethical and political topic. From a Christian point of view we deal with Buddhism as a religion. The heritage of Gautama Buddha has lead to reach forms of devotion, cults and practicing spirituality. The follower of his preachings realized himself under the conditions of his human being. He offers in temples, he worships in rich liturgies in front of the statues of the various reincarnations of the founder. We are impressed by the rich religious monuments in the history of Buddhist arts. Christians and Buddhists chare in this respect what is characteristic for man and his religion. Man is not the master of his life. He himself is not his own guarantee for having peace in this life and afterwards. So far the Christian-Buddhist dialogue had it common concern in the religious dimension. This has changed. We meet the modern Buddhist thinkers in different fields. Peaceful coexistence has become a matter of goodwill of man. It refers to the conflicts within our society and among nations. In this situation we might remind our Buddhist partners that the post-religious situation of man cannot offer the key to real and true peace which we are longing for. Which lesson might we learn from our modern Buddhist partners in dialogue? We ourselves must be careful that we do not separate our longing for peace from the source and fundament for such peace: Jesus Christ has not just left us a program for practicing a peaceful coexistence. His mission was not finished by giving just an example which he left for us. Faith in him as the source of peace includes him in his presence with us. The early Christian documents of the believers in the New Testament include always this new partic-

\footnotetext{
${ }^{8}$ Ibidem, p. 105.
} 
ipation in the everlasting, eternal and unlimited peace which he himself is. This specific Christian participation in peace must remain our concern in our dialogue with other men in other religions. Here we meet partners in the same dimension. The socio-political realm of the reduced secular Buddhist thinkers can only be the beginning of the dialogue. We are still in the entrance, not yet in the center of what we already have in common together.

I summarize:

1. Asian religions - mainly Hinduism and Buddhism - present themselves as an orientation for a worldwide universal human society.

2. They proclaim their religious messages as saving paths leading out from individual, national and social conflicts.

3. This reference of their own religious values to a general human ethic for peace is the fruit of an early orientation in and exchange with Western philosophy in general and with Christian values especially.

4. As Christians we share their conviction: Peace cannot be safeguarded by man's good-will and efforts

5. For the Christian faith any attempt of reaching and preserving peace among men is seen as an anonymous searching and longing for God's own peace-making action through his divine son Jesus Christ.

6. Our dialogue with men of other religions therefore cannot be restricted to mere human steps and efforts. We estimate highly their re-interpretations of their traditions in cooperation for a worldwide appeasement of mankind.

7. We have to lead our partners in dialogue toward this hidden divine base of our common struggle for peace - a struggle which unites us already.

8. By our partners in this ongoing dialogue we ourselves are reminded: Our contribution in this dialogue also cannot be limited to the secular expectations of political and social peacemaking. We are challenged to give the full answer of what has been made known to us in the revelation in Christ Jesus. We owe to them the full answer of what has been given to us:

It is "the hope" - as St. Paul says (Rom 15,13) - "which fulfills us with all joy and with all peace in faith to become rich in the power of the Holy Spirit."

\section{Kwestia „pokoju” w dialogu chrześcijan z religiami Azji}

\section{Streszczenie}

Horst Bürkle zauważa, że pojęcie pokoju w hinduizmie i buddyzmie jest owocem dialogu międzyreligijnego oraz wpływu religii chrześcijańskiej. Ukazuje współczesne reinterpretacje wspomnianych religii przez Gandhiego (hinduizm) oraz K. Nichitani i K.N. Jayatilleke (buddyzm). Opierając się na dokumentach pierwszego $\mathrm{z}$ wymienionych, prezentuje on sposób, w jaki indyjski my- 
śliciel pojmował pokój w sytuacjach społecznego konfliktu. Reinterpretacja budyzmu przez współczesnych reprezentantów religii ujawnia możliwość zastosowania pojęcia pokoju-nirwany w wymiarze społecznym. H. Bürkle usiłuje ukazać wspólne płaszczyzny w budowaniu pokoju przez wyznawców chrześcijaństwa oraz religii azjatyckich. Autor dochodzi do wniosku, że w dialogu z innymi religiami nie można ograniczać się jedynie do czysto politycznych kwestii związanych z pokojem, lecz opierając się na współczesnych reinterpretacjach religii azjatyckich, należy prowadzić go w kierunku ukrytego wspólnego fundamentu, jakim jest Bóg, a dla chrześcijan Chrystus - źródło prawdziwego pokoju.

\section{Stowa kluczowe}

pokój, religia, dialog, chrześcijaństwo, Azja

\section{Keywords}

peace, religion, dialogue, christianity, Asia 